\title{
COMPARISON OF STRUCTURE AND MECHANICAL PROPERTIES OF NODULAR CAST IRONS AFTER CASTING AND AFTER HEAT TREATMENT
}

\begin{abstract}
The paper deals with the influence of charge composition on microstructure and mechanical properties of synthetic nodular cast irons after casting and after heat treatment (ferritizing annealing and isothermal heat treatment). Chemical composition of individual melts was regulated alternatively by carburizer and ferrosilicon (FeSi) or metallurgical silicon carbide $(\mathrm{SiC})$. The results of experiments show that $\mathrm{SiC}$ additive positively influences the microstructure as well as mechanical properties of nodular cast iron, especially in specimens from the melts with higher ratio of steel scrap in the charge.
\end{abstract}

Keywords: nodular cast iron, ferritizing annealing, isothermal heat treatment

\section{Introduction}

In recent years, the production of nodular cast iron has been from an economic point of view orientated to synthetic melts where a part of more expensive pig iron in a metal charge is substituted for cheaper steel scrap. The transition from the traditional use of pig iron (classical melts) to synthetic nodular cast iron prepared from steel scrap requires the regulation of chemical composition of melt. Steel scrap has low content of silicon therefore increasing of content of silicon in the melt to eutectic composition $\left(\mathrm{S}_{\mathrm{C}} \sim 1\right)$ is reached by using of ferrosilicon $(\mathrm{FeSi})$ or metallurgical silicon carbide ( $\mathrm{SiC}$ ) additive. Nowadays, there is the tendency to use metallurgical silicon carbide as a siliconizing as well as carburizing additive instead of ferrosilicon. SiC additive increases the number of crystallisation nuclei of graphite in the melt, consequently the number of graphitic nodules per unit of area is increased (the size of graphitic nodules is decreased) and at the same time the susceptibility to occurrence of carbide in the structure is decreased. Other influence of $\mathrm{SiC}$ additive is its ferritizing effect therefore the content of ferrite in the matrix is increased (VENKATESWARAN S. 1989).

The technological foundry literature describes the addition of $\mathrm{SiC}$ to the cast iron melt frequently as having a special pre-inoculating effect. This influence is well

1 Ing. PhD., University of Žilina, Faculty of Mechanical Engineering, Department of Materials Engineering, e-mail: alan.vasko@fstroj.uniza.sk

2 Ing. PhD., University of Žilina, Faculty of Mechanical Engineering, Department of Materials Engineering, e-mail: juraj.belan@fstroj.uniza.sk

3 Ing. PhD., University of Žilina, Faculty of Mechanical Engineering, Department of Materials Engineering, e-mail: lenka.kucharikova@fstroj.uniza.sk 
documented in the case of grey cast iron and has also been observed to some extent at industrial as well as at laboratory experiments in the case of nodular cast iron (BENECKE T. 1994).

The paper deals with the influence of charge composition (different ratio of pig iron and steel scrap in the charge and $\mathrm{FeSi}$ or $\mathrm{SiC}$ additive) on microstructure and mechanical properties of synthetic nodular cast irons after casting and after heat treatment (ferritizing annealing and isothermal heat treatment).

\section{Experimental material and methods}

Two series of five melts of nodular cast iron were used for experiments. The resultant melts have approximately the same chemical composition but this was achieved by different charge composition (Tab. 1). The basic charge of individual melts was formed by different ratio of pig iron and well selected steel scrap. For the regulation of chemical composition the additive of carburizer and silicon carbide (in melts A1 to A5) or ferrosilicon (in melts B1 to B5) was used. For modification $\mathrm{FeSiMg} 7$ modifier was used and for inoculation FeSi75 inoculant was used.

Table 1. Charge composition of experimental melts

\begin{tabular}{|c|c|c|c|c|c|}
\hline $\begin{array}{c}\text { Melt } \\
\text { number }\end{array}$ & $\begin{array}{c}\text { pig iron } \\
(\%)\end{array}$ & $\begin{array}{c}\text { steel scrap } \\
(\%)\end{array}$ & $\begin{array}{c}\text { additive } \\
\text { in melts } \mathrm{A1}-\mathrm{A5}\end{array}$ & $\begin{array}{c}\text { additive } \\
\text { in melts B1-B5 }\end{array}$ & $\begin{array}{c}\text { modifier \& } \\
\text { inoculant }\end{array}$ \\
\hline A1 / B1 & 80 & 20 & \multirow{5}{*}{$\begin{array}{c}\text { carburizer } \\
+\mathrm{SiC} 90\end{array}$} & \multirow{5}{*}{$\begin{array}{c}\text { carburizer } \\
+\mathrm{FeSi} 75\end{array}$} & \multirow{5}{*}{$\begin{array}{l}\text { FeSiMg7 } \\
+ \text { FeSi75 }\end{array}$} \\
\hline A2 / B2 & 60 & 40 & & & \\
\hline A3 / B3 & 40 & 60 & & & \\
\hline A4 / B4 & 20 & 80 & & & \\
\hline A5 / B5 & 0 & 100 & & & \\
\hline
\end{tabular}

Source: own study

Two different types of heat treatment of specimens were made, namely ferritizing annealing and isothermal heat treatment.

The ferritizing annealing consisted of heating to the temperature $680^{\circ} \mathrm{C}$, holding time at this temperature for 4 hours, slow cooling to the temperature $580^{\circ} \mathrm{C}$ in a furnace and after-cooling to the ambient temperature in the air.

The isothermal heat treatment consisted of austenitization and following isothermal transformation. The austenitization temperature was $920^{\circ} \mathrm{C}$ and the holding time at this temperature was 30 minutes. The isothermal transformation of austenite was realized in AS 140 salt bath at the temperatures 380 and $250^{\circ} \mathrm{C}$ and the holding 
time at these temperatures was 90 minutes. After-cooling to the ambient temperature was realized in the air (KARSAY S. I. 1996, GEDEONOVÁ Z. 2000).

The metallographic analysis of specimens of basic material (after casting) and specimens after heat treatment was made by the light metallographic microscope Neophot 32. The microstructure was evaluated according to STN EN ISO 945 (STN 42 0461) and by automatical image analysis (using NIS Elements software). The image analysis was used for the evaluation of number of graphitic nodules per unit of area (disregarding the size of nodules) and content of ferrite in the matrix (SKOČOVSKÝ P. 2007).

The tensile test was made according to STN EN ISO 6892-1 by means of the testing equipment ZDM 30 with loading range $\mathrm{F}=0$ to $50 \mathrm{kN}$. The impact bending test was made according to STN EN ISO 148-1 by means of the Charpy hammer with nominal energy $300 \mathrm{~J}$. The Brinell hardness test was made according to STN EN ISO 6506-1 by means of the testing equipment CV 3000 LDB with a hardmetal ball of diameter $\mathrm{D}=5 \mathrm{~mm}$ forced into specimens under the load $\mathrm{F}=2450 \mathrm{~N}$ (VAŠKO A. 2014).

\section{Experimental results and discussion}

\subsection{Analysis of specimens after casting}

From a microstructural point of view all specimens of basic material (after casting) are ferrite-pearlitic nodular cast irons with different content of ferrite and pearlite in the matrix, different size of graphite and number of graphitic nodules per $\mathrm{mm}^{2}$. Graphite occurs only in a perfectly-nodular (VI) and imperfectly-nodular (V) shape in all the specimens. For comparison, Fig. 1 shows the microstructure of specimens from the melt $\mathrm{A} 3$ (with $\mathrm{SiC}$ additive) and the melt $\mathrm{B} 3$ (with $\mathrm{FeSi}$ additive) with the same ratio of steel scrap in the charge. The results of evaluation of microstructure of chosen specimens of basic material (after casting) according to STN EN ISO 945 (STN 42 0461) and by image analysis are presented in Tab. 2.

Mechanical properties (tensile strength $\mathrm{R}_{\mathrm{m}}$, elongation $\mathrm{A}$, absorbed energy $\mathrm{K} 0$ and Brinell hardness HB) depend especially on the character of matrix (content of ferrite and pearlite) and also on the size and number of graphitic nodules. The results of mechanical tests are given in Tab. 3. The mechanical properties of specimens from the melts with $\mathrm{SiC}$ additive (i.e. melts $\mathrm{A} 1$ to A5) are generally better than mechanical properties of specimens from the melts with FeSi additive (i.e. melts B1 to B5), especially in case of the specimens with higher ratio of steel scrap in the charge. 
Quality. Production. Improvement

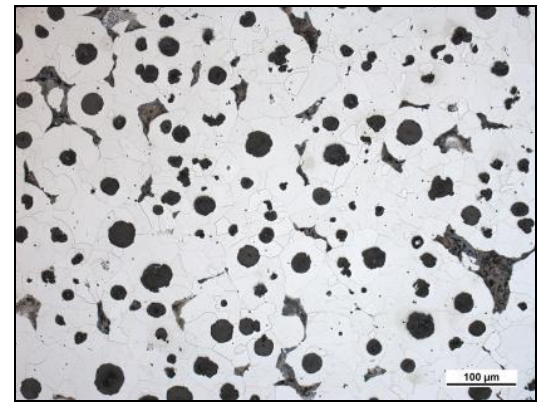

a) specimen $\mathrm{A} 3$ (with $\mathrm{SiC}$ additive)

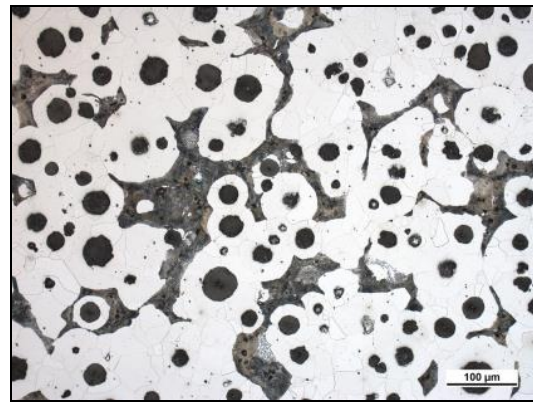

b) specimen B3 (with FeSi additive)

Fig. 1. Microstructure of chosen specimens after casting -ferrite-pearlitic nodular cast Source: own study irons, etched $1 \%$ Nital.

Table 2. Microstructure of chosen specimens after casting

\begin{tabular}{|c|c|c|c|}
\hline Melt number & $\begin{array}{c}\text { Microstructure } \\
\text { STN EN ISO 945 } \\
\text { (STN 42 0461) }\end{array}$ & $\begin{array}{c}\text { content of } \\
\text { ferrite } \\
(\boldsymbol{\%})\end{array}$ & $\begin{array}{c}\text { number of graphitic } \\
\text { nodules } \\
\left(\mathbf{m m} \mathbf{m}^{-2}\right.\end{array}$ \\
\hline A1 & $60 \% \mathrm{VI} \underline{5} / 6+40 \% \mathrm{~V} 6-\mathrm{Fe} 80$ & 61.6 & 104.3 \\
\hline A3 & $80 \% \mathrm{VI} 6+20 \% \mathrm{~V} 6-\mathrm{Fe} 94$ & 74.0 & 199.8 \\
\hline A5 & $70 \% \mathrm{VI} 5 / \underline{6}+30 \% \mathrm{~V} 6-\mathrm{Fe} 94$ & 78.0 & 179.8 \\
\hline B1 & $70 \% \mathrm{VI} \underline{5} / 6+30 \% \mathrm{~V} 6-\mathrm{Fe} 55$ & 50.8 & 126.5 \\
\hline B3 & $70 \% \mathrm{VI} 5 / \underline{6}+30 \% \mathrm{~V} 6-\mathrm{Fe} 80$ & 65.2 & 151.0 \\
\hline B5 & $70 \% \mathrm{VI} 5 \underline{6}+30 \% \mathrm{~V} 6-\mathrm{Fe} 80$ & 56.0 & 157.6 \\
\hline
\end{tabular}

Source: own study

Table 3. Mechanical properties of chosen specimens after casting

\begin{tabular}{|c|c|c|c|c|}
\hline $\begin{array}{c}\text { Melt } \\
\text { number }\end{array}$ & $\begin{array}{c}\text { tensile strength } \\
\mathbf{R} \mathbf{m}(\mathbf{M P a})\end{array}$ & $\begin{array}{c}\text { elongation } \\
\mathbf{A}(\mathbf{\%})\end{array}$ & $\begin{array}{c}\text { absorbed energy } \\
\mathbf{K 0}(\mathbf{J})\end{array}$ & $\begin{array}{c}\text { Brinell hardness } \\
\text { HB }\end{array}$ \\
\hline A1 & 500.8 & 1.3 & 6.4 & 209.0 \\
\hline A3 & 539.0 & 4.0 & 30.6 & 188.0 \\
\hline A5 & 515.7 & 3.7 & 17.2 & 183.5 \\
\hline B1 & 367.1 & 1.7 & 8.4 & 185.0 \\
\hline B3 & 462.6 & 2.7 & 24.0 & 175.5 \\
\hline B5 & 462.6 & 2.7 & 19.2 & 182.0 \\
\hline
\end{tabular}

Source: own study 


\subsection{Analysis of specimens after ferritizing annealing}

From a microstructural point of view the specimens after ferritizing annealing are ferritic nodular cast irons. The content of ferrite in the matrix is $98 \%$ or more; pearlite occurs only in a few isolated cases. The shape, size and number of graphitic nodules in the specimens after ferritizing annealing are not changed in comparison with the specimens of basic material (after casting).

For comparison, Fig. 2 shows the microstructure of specimens after ferritizing annealing from the melt $\mathrm{A} 3$ (with $\mathrm{SiC}$ additive) and the melt $\mathrm{B} 3$ (with $\mathrm{FeSi}$ additive) with the same ratio of steel scrap in the charge. The content of ferrite in specimens after ferritizing annealing from the melts with $\mathrm{SiC}$ additive (melts A1 to A5) is generally higher than in specimens from the melts with $\mathrm{FeSi}$ additive (melts $\mathrm{B} 1$ to B5). This relates with the content of ferrite in specimens of basic material (after casting). The specimens after casting from the melts with $\mathrm{SiC}$ additive have higher content of ferrite, therefore they need shorter holding time at ferritizing temperature than specimens from the melts with $\mathrm{FeSi}$ additive to obtain ferritic matrix.

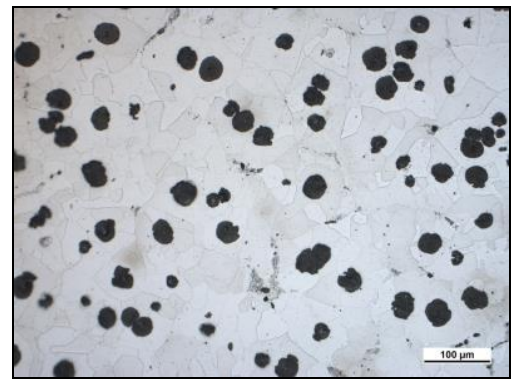

a) specimen $\mathrm{A} 3$ (with $\mathrm{SiC}$ additive)

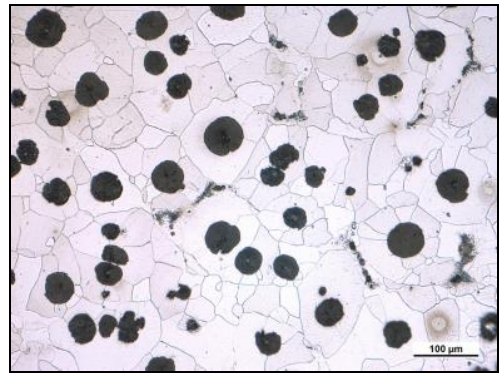

b) specimen B3 (with FeSi additive)

Fig. 2. Microstructure of chosen specimens after ferritizing annealing-ferritic nodular cast irons, etched $1 \%$ Nital.

Source: own study

\subsection{Analysis of specimens after isothermal heat treatment}

The specimens after isothermal heat treatment are austempered ductile irons (ADI). The matrix of ADI consists of acicular ferrite and retained austenite (this mixture is called ausferrite). Technical literature often describes this matrix as bainite (DORAZIL E. 1985, SKOČOVSKÝ P. 2014).

The specimens with the temperature of isothermal transformation of austenite $380^{\circ} \mathrm{C}$ have the matrix created by upper bainite and retained austenite (Fig. 4.3). The specimens with the temperature of isothermal transformation of austenite $250^{\circ} \mathrm{C}$ have 
the matrix created by lower bainite and retained austenite (Fig. 4). The difference is in the size of individual particles of both phases and also in their relative amounts in the structure. Figs. 3 and.4 clearly reveal that the microstructure following the treatment at $250^{\circ} \mathrm{C}$ is finer in comparison with the microstructure resulting from the treatment at $380^{\circ} \mathrm{C}$. This difference results in higher mechanical properties (hardness) of the ADI austempered at the lower temperature (Tab. 4).

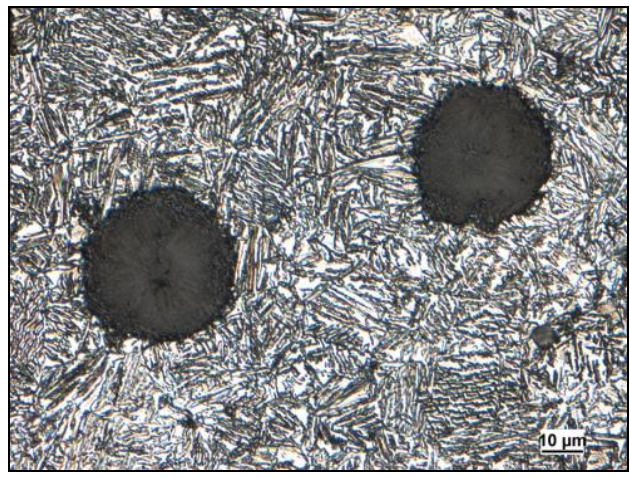

a) specimen $\mathrm{A} 3$ (with $\mathrm{SiC}$ additive)

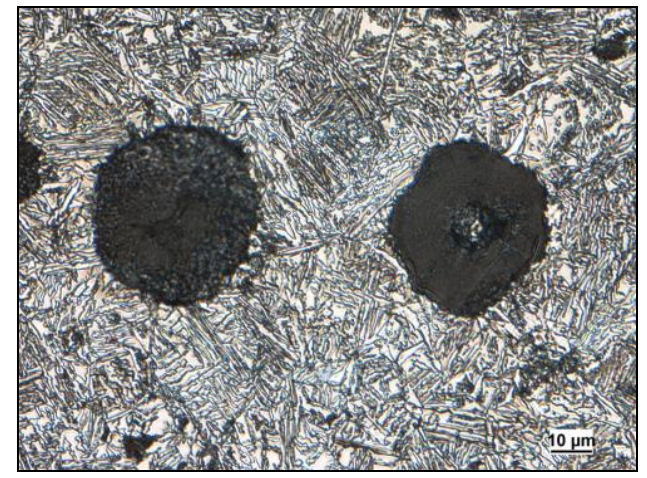

b) specimen B3 (with FeSi additive)

Fig. 3. Microstructure of chosen specimens after isothermal heat treatment $\left(380^{\circ} \mathrm{C} / 90\right.$ min.) - ADI, matrix created by upper bainite and retained austenite, etched $1 \%$ Nital. Source: own study

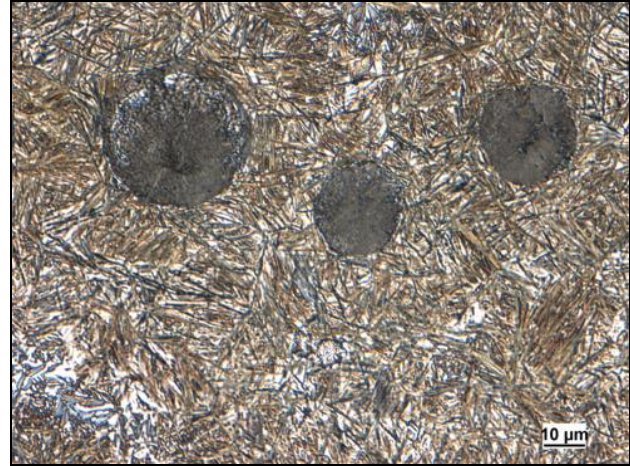

a) specimen $\mathrm{A} 3$ (with $\mathrm{SiC}$ additive)

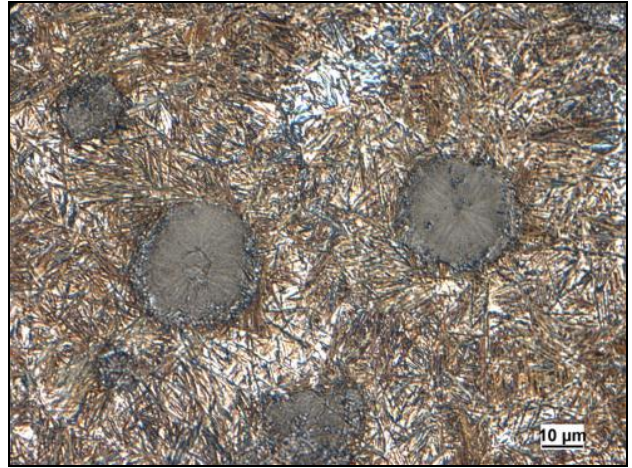

b) specimen B3 (with FeSi additive)

Fig. 4. Microstructure of chosen specimens after isothermal heat treatment $\left(250^{\circ} \mathrm{C} / 90\right.$ min.) - ADI, matrix created by lower bainite and retained austenite, etched $1 \%$ Nital. Source: own study 
The content of retained austenite is slightly lower in specimens from the melts with $\mathrm{SiC}$ additive (melts $\mathrm{A} 1$ to A5) than in specimens from the melts with $\mathrm{FeSi}$ additive (melts B1 to B5). The shape, size and number of graphitic nodules in the specimens after isothermal heat treatment are not changed in comparison with the specimens of basic material (after casting).

Table 4. Microstructure and hardness of chosen specimens after heat treatment

\begin{tabular}{|c|c|c|c|c|c|c|}
\hline \multirow[t]{2}{*}{$\begin{array}{c}\text { Melt } \\
\text { number }\end{array}$} & \multicolumn{2}{|c|}{ after ferritizing annealing } & \multicolumn{2}{|c|}{$\begin{array}{l}\text { after isothermal heat } \\
\text { treatment }\left(380^{\circ} \mathrm{C} / 90 \mathrm{~min} .\right)\end{array}$} & \multicolumn{2}{|c|}{$\begin{array}{l}\text { after isothermal heat } \\
\text { treatment }\left(250{ }^{\circ} \mathrm{C} / 90\right. \\
\text { min. })\end{array}$} \\
\hline & matrix & HB & matrix & HB & matrix & HB \\
\hline A1 & \multirow{3}{*}{ ferrite } & 200 & \multirow{6}{*}{$\begin{array}{l}\text { upper bainite }+ \\
\text { retained } \\
\text { austenite }\end{array}$} & 262 & \multirow{6}{*}{$\begin{array}{c}\text { lower bainite } \\
+ \\
\text { retained } \\
\text { austenite }\end{array}$} & 390 \\
\hline $\mathbf{A 3}$ & & 182 & & 264 & & 386 \\
\hline A5 & & 184 & & 262 & & 369 \\
\hline B1 & \multirow{3}{*}{$\begin{array}{c}\text { ferrite } \\
(>98 \%)\end{array}$} & 169 & & 251 & & 369 \\
\hline B3 & & 176 & & 249 & & 386 \\
\hline B5 & & 169 & & 244 & & 381 \\
\hline
\end{tabular}

Source: own study

The results of evaluation of mechanical properties (Brinell hardness HB) of chosen specimens after heat treatment (ferritizing annealing and isothermal heat treatment) are given in Tab. 4. The hardness is generally higher in specimens from the melts with $\mathrm{SiC}$ additive (melts A1 to A5) than in specimens from the melts with $\mathrm{FeSi}$ additive (melts B1 to B5).

\section{Conclusions}

The substitution of a part of pig iron for steel scrap in the charge of nodular cast iron has a considerable economic contribution. For the regulation of chemical composition of melt it is advantageous to use metallurgical $\mathrm{SiC}$ additive which has been used in this work as an alternative additive instead of FeSi in melts with a different ratio of pig iron and steel scrap in the charge.

Increasing ratio of steel scrap in the charge together with increasing amount of $\mathrm{SiC}$ or FeSi additive influence the microstructure as well as mechanical properties of nodular cast iron. The content of ferrite in the matrix is increased, the number of graphitic nodules per unit area is increased and the occurrence of undesirable cementite is eliminated; consequently the mechanical properties are improved. This 
positive influence is more significantly shown in specimens from the melts with $\mathrm{SiC}$ additive. After ferritizing annealing the specimens have ferritic matrix; pearlite occurs only in a few isolated cases, especially in specimens from the melts with $\mathrm{FeSi}$ additive. Therefore it is necessary to use longer holding time at ferritizing temperature to obtain ferritic matrix. After isothermal heat treatment the specimens have matrix created by upper or lower bainite and retained austenite. The content of retained austenite is slightly lower in specimens from the melts with $\mathrm{SiC}$ additive than in specimens from the melts with $\mathrm{FeSi}$ additive.

\section{Acknowledgements}

This work has been supported by the Scientific Grant Agency of Ministry of Education, Science, Research and Sport of Slovak Republic, grant project VEGA No. 1/0533/15 and by the Culture and Educational Grant Agency of Ministry of Education, Science, Research and Sport of Slovak Republic, grant project KEGA No. 049ŽU-4/2017.

\section{Bibliography}

1. Benecke T., Venkateswaran S., Schubert W. D., LuX B. 1994. Investigation of the influence of silicon carbide in the production of ductile cast iron. „Foundryman”. Vol. 87, No. 10, p. 355-360.

2. DORAZIL E. 1985. Vysokopevná bainitická tvárna liatina. Academia. Praha.

3. GedeOnOvÁ Z., JelČ I. 2000. Metalurgia liatin. HF TU. Košice.

4. KARSAY S. I. 1996. Tvárna liatina I. Výroba. Fompex. Trenčín.

5. SKOČOVSKÝ P., VAŠKO A. 2007. Kvantitatívne hodnotenie štruktúry liatin. EDIS. Žilina.

6. SkoČOvskÝ P., BoKƯVkA O., KoneČNÁ R., TIllovÁ E. 2014. Náuka o materiáli. EDIS. Žilina.

7. SKOČOVSKÝ P., PODRÁBSKÝ T. 2005. Grafitické liatiny. EDIS. Žilina.

8. VAŠKO A., SKOČOVSKÝ P. 2014. Vlastnosti a použitie kovových materiálov. EDIS. Žilina.

9. Venkateswaran S., Wilfing J., Schubert W. D., LuX B., Benecke T. 1989. Influence of $\mathrm{SiC}$ and FeSi additions on the microstructure, cooling curve and shrinkage porosity of ductile iron. In: Physical metallurgy of cast iron. Tokyo, Japan, p. 171-178. 